\title{
Hegemonik İdeoloji, Birey ve Psiko-Politik Etkileşimler: Persepolis Filmi Örnekliği
}

\author{
Burcu Şüheda Şimşek* \\ Sakarya Üniversitesi \\ Ekmel Geçer** \\ Sağlık Bilimleri Üniversitesi
}

\section{Öz}

Louis Althusser ideolojiyi siyasal ve toplumsal rolleri bulunan bir tasarım olarak değerlendirmiş; temel fonksiyonunu ise, toplumsal yapının ve üretim ilişkilerinin devam ettirilmesi olarak görmüştür. Birey; farkında olmadan ya da milliyet, tarihsel öğrenim, sosyo-politik ortam ve sonrasında oluşan psikolojik yaklașımlar gibi nedenlerle doğruluğuna inanarak, ideolojik etkiye maruz kalmaktadır. Bu yönlendirme sürecinde birey, yine Althusser'in ifadesiyle, devletin ideolojik aygıtları olan eğitim, din, siyaset, kültür, aile, haberleşme ve sanat gibi unsurlardan etkilenir ya da mevcut bakış açısını güçlendirmek için onlardan faydalanır. Bu bağlamda elinizdeki makale; Althusser'in ideoloji kavramını, devletin ideolojik aygıtları çerçevesinde açıklamayı ve çağrılma aracılığıyla özneleştirilmiş bireyin ideolojiyle çevrelenmiş hayatında, söz hakkı olup olmadığını tartışmayı amaçlamaktadır. Diğer bir ifadeyle çalışma; zamanla ideolojilerin mücadele alanı olan hegemonik süreçlerin bireyler üzerindeki etkilerini anlama çabasının ürünüdür. Bu amaçla; bir animasyon filmi olan Persepolis örnekliğinde, Althusser'in devletin ideolojik aygitları kuramının ne şekilde ve hangi kalıplarla yansıtıldı̆̆ı ortaya çıkarılmaya çalışılmıştır. Filmin analizi doküman incelemesi yoluyla yapılmış, yöntem olarak önceden belirlenmiş ölçütleri karşılayan olguların çalışıldığı ölçüt örnekleme metodu benimsenmiştir. Yapılan değerlendirmede; devletin, ideolojik aygıtlar aracılığıyla birey üzerinde hegemonya kurmaya çalıștığı, bireyin ise ancak Gramsci'nin alternatif hegemonya alanlarını kullanarak ve Hall'un bahsini ettiği okuma süreçlerini geliștirmesiyle bu durumdan kurtulabileceği, ancak bunun gerçekleşmesinin hegemonyanın derecesine bağlı olarak yoğun işletildiği dönemlerde çok zor olduğu anlașılmıştır. Bununla birlikte, hegemonyanın güçlü ideolojik etkisine rağmen, egemen doktrinlerden farklı bir yaklaşıma sahibi olmanın, her koşulda mümkün olduğu sonucuna varılmıștır.

\section{Anahtar Kelimeler}

ideoloji, hegemonya, devletin ideolojik aygıtları, politik psikoloji, sinema

* Doktora Öğrencisi, Sakarya Üniversitesi, Sosyal Bilimler Enstitüsü, İletişim Bilimleri Anabilim Dalı, burcusuheda@hotmail.com, ORCID ID: 0000-0002-0010-3443

** Doç. Dr., Sağlık Bilimleri Üniversitesi, Yaşam Bilimleri Fakültesi, Psikoloji Bölümü, ekmelgecer@sakarya.edu.tr, ORCID ID: 0000-0003-3367-2236 


\title{
Hegemonic Ideology, Individual and Psycho-Political Interactions:
}

\author{
The Case Of Persepolis Movie
}

\begin{abstract}
Louis Althusser defines ideology as a design that undertakes social and political roles and states that the main function of ideology is the sustainability in social structure and production relationships. An individual either unconsciously or through her/his socio-political, nationalist and historical backgrounds and because of the adventitiously merging psychological approaches, intentionally is influenced by the ideologies. According to him, the individual during the process of this ideological interactions is influenced by the state apparatus such as education, religion, politics, culture, family, media and art or s/he benefits from them to empower her/his present approaches. In this regard, this study aims to examine Althusser's ideology approach within the context of ideological state apparatus and tries to find out if the individuals have right to say in an atmosphere where they have been surrounded by ideologies. In other words, this article is a study of understanding the influence of the hegemonic processes which in the long run become the battlefield of ideologies. Therefore, through the case of Persepolis, this study aims to analyse the reflections of Althusser's ideological state apparatus theory in an animated movie how and in what forms the theory is represented. The movie analysed through document analysis and the method at this review has been criterion sampling that meet some predetermined criterion of importance. The analysis suggests that the state, tries to structure a hegemony on the individuals through the ideological apparatus and the individuals, although seems quite difficult especially when and where hegemony is dominated, can only get rid of this influence by using Gramsci's alternative hegemony fields and developing the reading process which Hall points out. The inquiry also suggests that despite the powerful ideological influence of the hegemony, it is always possible to have different approaches under any circumstances.
\end{abstract}

\section{Keywords}

ideology, hegemony, ideological state apparatus, political psychology, cinema

\section{Extended Abstract}

Ideology is an issue or concept which many authors sensitively focus on. Marx, being one of them, states that those who control the visible or solid forms of the ideology also desire to control the mental forms of it (Eagleton, 2011: 168) and therefore believes that ideology is a negative cover which hides the inequalities in the society. Ideology in this context is a mistaken awareness that demolishes the link between the individual and the reality. Being one of the scholars who structure the Marxist ideology, Louis Althusser, on the other hand, defines ideology as a practice which functionalizes to re-produce all relationships. In this regard, Althusser opposes seeing the ideology as a "mis- 
taken awareness" and approaches it as a life-style regarding the relationship among the individuals and the existing conditions. Having said that, he defines ideology as a design that undertakes social and political roles and states that the main function of ideology is the sustainability in social structure and production of relationships. An individual either unconsciously or through her/his socio-political, nationalist and historical backgrounds and because of the adventitiously merging psychological approaches, intentionally is influenced by the ideologies. According to him, the individual during the process of this ideological interactions is influenced by the state apparatus such as education, religion, politics, culture, family, media and art or s/he benefits from them to empower her/his present approaches (Althusser, 2010).

In this regard, this study aims to examine Althusser's ideology approach within the context of ideological state apparatus and tries to find out if the individuals have right to say in an atmosphere where they have been surrounded by ideologies. In other words, this article is a study of understanding the influence of the hegemonic processes which in the long run become the battlefield of ideologies. The study through this way will be able to demonstrate how Althusser's approach is successful in showing the ability of the hegemonic ideology to be that influential. The way in studying Althusser's "ideological state apparatus" in this article is analysing a movie named Persepolis (2007) which is a French-American co-produced one. Through the case of Persepolis, this study aims to analyze the reflections of Althusser's ideological state apparatus theory in an animated movie how and in what forms the theory is represented. On the other hand, it is better to note that the movie is capable to suggest how ideology influences an individual's life and through which apparatus. In Stuart Hall's approach, which is influenced by Gramsci's counter-hegemony, this study, thereby, will be able to analyze the ability of an individual in developing a dissenting reading. Gramsci's counter-hegemony (Damgaard, 2018: 21) in this regard defines "the way people develop ideas and discourse to challenge dominant assumptions, beliefs and established patterns of behaviour."

With no doubt, cinema is able to influence the masses through its features such as identification and making the audience envious. While some movies want to give some precious approaches regarding any subjects, some others prefer to do this in a covered way. Hegemonic powers in this regard, in Althusser's terms, use cinema to impose their ideologies and change the way the individuals behave or think. Yet, although cinema being one of the tools to show the audience the realities regarding some specific issues, it has mostly been misused by the powers and have not been able to get rid of being used as an ideological apparatus by them. Despite the democratic developments in the globe and the improvement in sustaining human rights; political, martial and/or economic powers still try to convey their messages through mass communication including cinema to make people have positive thoughts 
about them. Thus, it will not be wrong to claim that cinema throughout its history has been using the political power vice versa. Even movies which do not have an ideological message may have a political intention such as de-politicising the audience and keep them away from the political debates. Adorno in this regard state that the productions of cultural industry are designed to keep us distracted, unable to understand ourselves and without a will to alter the political reality (Adorno, 2002: 49).

Within this context, the case of Persepolis will be able to demonstrate how a movie is capable to show the change in an individual's opinions, beliefs, and approaches. To be able to answer our research questions, the movie examined through document analysis and the method at this review has been criterion sampling that meets some predetermined criterion of importance. Therefore, the study has a qualitative method and the document in this analysis is the Persepolis movie.

Based on Althusser's ideological state apparatus and the debates around it in the literature such as Chomsky and Herman's manufacturing consent and Hall's discourse and ideology (2018), the main aim here is to examine the relationship between the individual and the ideology which is embodied in the movie. In other words, through the movie, the study will see if the movie has been able to show the practicality of ideological state apparatus which is mostly featured as media, religion, education and social norms. Of course, it is not easy to state that the Persepolis movie is a material manifestation of ideological state apparatus which includes all mentioned by Althusser. Yet the movie is capable to illustrate how ideological state apparatus is able to alter an individual's approaches, beliefs, and opinions.

Through a narrative method, the scenes of the picture analysed within the context of Althusser's approach. In this animated movie, the ideological state apparatus was gathered by the hegemonic powers and the mainstream ideology was re-told and re-produced constantly through many apparatuses which belong to the state and the powers. The analysis of the movie suggests that the state, tries to structure a hegemony on the individuals through the ideological apparatus and the persons, although seems quite difficult especially when and where hegemony is dominated, can only get rid of this influence by developing the reading process which Hall points out. The inquiry also suggests that despite the powerful ideological influence of the hegemony, it is always possible to have different approaches under any circumstances. 


\section{Giriş}

İdeoloji bireylerin hayatını yönlendirme becerisiyle birçok kuramcının üzerinde hassasiyetle durduğu konular arasındadır. Van Dijk, ideolojinin ilk kez 18 yy. sonunda Fransız düşünür Tracy tarafından ortaya atıldığından beri; insanın bilişsel düzeyinin araştırıldığı "düşünce bilimi" olarak, bir grubun üyelerinin toplumsal, siyasi ve dini köklü inançlarını ifade eden "inançlar sistemi" olarak ve statükoyu meşrulaştırmak için kullanılan popüler ancak yanıltıcı inançlar olan "yanlış bilinç" olarak tanımlamalarının yapılabileceğini belirtmektedir (2015: 16-18).

Louis Althusser; Marksizmin ideoloji segmentini yeniden kurgulayan bir düşünürdür. İdeolojiyi tüm ilişkileri yeniden üretmek için işleyen bir pratik olarak değerlendirmektedir. Althusser bu görüşleriyle, ideolojinin yanlış bilinç olarak görülmesine karşı çıkmakta ve ideolojiyi bireylerin kendi aralarındaki ilişkiler ile varoluş koşullarını yaşama biçimi olarak değerlendirmektedir (Althusser, 2010: 169-171).

Antonio Gramsci ise; ideolojilerin toplumsal deneyimlerimi açılayacak şekilde direnç de üretebildiğini öne sürer. Bireylerde ideoloji aracılığıyla psikolojik bir geçerlik üretildiğini ve bu sayede insanların durumlarının farkına varmasını sağlayan, harekete geçiren ve savaştıran hegemonik bir mücadele alanı oluşacağını ifade eder (Gramsci, 2016: 59). Bununla birlikte Fiske'e göre ideoloji kuramları son değerlendirmede; tahakkümün sürdürülme biçimlerine, etkililiğinin derecesine ya da karşılaştığı dirençlerin boyutuna göre farklılık gösterse de temelde sınıf tahakkümünü sürdürme çabası olduğu konusunda hemfikirdirler (Fiske, 2003: 226).

Hegemonya konusunu ilk ortaya atan kendisi olmamakla birlikte, hegemonya çalışmalarındaki detaylı çözümlemeleriyle ilk akla gelen isim Gramsci'dir. Ancak egemen ideolojinin olumsuz etkilerinin değerlendirildiği makalemizin asll kaynağı Gramsci değil Althusser'dir. Çünkü Hall, Lumley ve McLennan de belirttiği gibi; Althusser devletin ideolojik aygıtları fikrini doğrudan Gramsci'nin Hapishane Defterleri'nden alacak kadar Gramsci'den etkilenmekle birlikte, Gramsci'nin kavramlarını yeniden üretmekte, eksik gördüğü sistemleşmeyi tamamlayan farklı bir bakış açısı geliştirmektedir. Gramsci ideolojiyi her sınıfın egemenlik kurma iliş̧kileri içinde olumlu yönde ele alırken; Althusser Gramsci'nin yaptığı sivil toplum politik toplum ayrımını gereksiz görmekte, hepsini devletin ideolojik aygitı olarak isimlendirmekte ve hegemonyayı 
sadece egemen sınıfın tahakkümü şeklinde olumsuz değerlendirmektedir (Gramsci, 2014: 199-202).

$\mathrm{Bu}$ çalışmaya konu olan temel sorunsal; ideolojinin bireyle arasında gerçekleşen ilişkiyi, yanlış bilinç olarak değerlendirilen Marksist gelenekten farklı olarak, yapısalcı düşüncenin önemli temsilcilerinden biri kabul edilen Althusser'in tanımını yaptığı devletin ideolojik aygıtları (DİA) bağlamında incelemektir. Althusser'in ideoloji kuramının, egemen ideolojinin kuşatıcılığını göstermedeki başarısının yanı sıra; karşılaştığı dirençlerle giriştiği mücadeleyi görmezden geldiği üzerinde durulacaktır. Bu temel yaklaşımdan beslenerek Fransız Amerikan ortak yapımı animasyon filmi Persepolis (2007) çerçevesinde, olumsuz ideolojik yaklaşım olarak egemen ideolojinin tahakküm alanları, ideolojinin birey yaşamına hangi aygıtlar aracılığıyla nasıl tesir ettiği ve sonuçta öznenin maruz kaldığı ideolojilere, Gramsci'nin karşı-hegemonya kavramı ve ondan etkilenen Stuart Hall'un tanımını yaptığı șekliyle; muhalif okuma geliştirebilme becerisi incelenecektir. Çalışmada amaç kuramsal temelin işleyişine şahitlik etmek ve yaşanan aldatmacaya farkındalık kazanmaktır.

Bu çerçevede yapılacak analize temel oluşturacak kuramsal arka plan olarak; ideoloji, DİA’nın işleyişleri ve Althusser'in eleştirisi üzerinden hegemonik mücadele alanları üzerinde durulacaktır. Yöntem aşamasında ise filmin anlatı (narrative) yöntemi kapsamında analizi yapılacaktır.

\section{İdeoloji: Kurgulanmış Anlam Dünyası}

Althusser, ideolojiyi üst yapı segmentleri içinde değerlendirmekte ve toplumsal yapının sürekliliğini sağlamadaki rolü üzerinde durmaktadır (Zengin, 2018: 53). Çalışmaya temel alacağımız şekliyle Althusser ideoloji hakkında birbiriyle ilintili üç önemli kurucu tez ortaya atmaktadır. Buna göre, İdeoloji gerçekliğin tam olarak temsil edilmesi olmayıp aksine bireylerin gerçek varoluş koşullarıyla ilişkilerinin hayali (imgesel) bir temsilidir. İdeoloji maddi bir var oluşa sahiptir. İdeoloji için bireyler özne niteliği taşımaktadır bu yüzden onları özne olarak çağırır, adlandırır (Althusser, 2010: 89-108).

İlk teze göre ideoloji; kaynağını maddi oluşumlardan alsa da gerçekliği değil bireylerin düşlediği ve tahayyül ettiği ilişkileri temsil etmektedir. Bu safhada bilinç düzeyindeki tasarımlar dâhil simgeler, mitler ve kavramlar özneye bağlı olarak yeniden tanımlanmakta ve yaşam pratiğine dönüştürülmektedir (Kazancl, 2002: 77). Diğer bir deyişle ideoloji; gerçek ilişkileri değil, bireylerden boyun eğmesi istenen gerçekle kurdukları hayali ilişkiyi tanımlamaktadır (Bank, 2016: 26). Öyleyse ideoloji maddi yaşam koşullarıyla ilişkili toplumsal bilinç biçimi değil; bireylerin kendi yaşam koşullarıyla ilişkisini hayali boyutta anlamlandırdığı bilinç ve bilinçdışı düzeyde tanıma ve/veya tanımama biçimidir (Althusser, 2002: 18). Bu durumda ideoloji bireyi hem düşünce sistemleri hem inançları hem sosyal yaşam biçimleri gibi her alanda kuşatarak verili 
ideolojilere mahkûm edecek ve özgür düşünme, özgür hareket etme yetisiyle birlikte tarafsız düşünme becerisini de köreltecektir (Sucu, 2012: 31).

İkinci tez olan ideolojinin maddi bir varoluşa sahip olması; birey üzerinde meydana getirdiği etkiyi ifade etmektedir. İdeolojinin içinde yaşayan öznenin belirli davranış kalıplarını benimseyerek, ideolojik aygıtta düzenlenmiş pratiklere katılmasını temsil etmektedir (Güngör, 2001: 226). Örneğin birey bir Yaratıcıya ya da adalete inanır. İnanca ilişkin düşünceleri kapsayan bilinç sayesinde, kurulu ideolojik düzenek bireyi; dua etme, tövbe etme ya da hukuk kurallarına tartışmasız boyun eğme, haksızlığa karşı çıkma gibi belirli davranışlara yönlendirmektedir (Althusser, 2010: 94-95). Böylece inançlar maddi gerçekliklere dönüşmektedir.

Son tezinde Althusser; ideolojik tanımanın bireyi özne haline getirmesini, çağırma metaforunu kullanarak somutlaştırmaktadır. İdeolojinin 'Hey, sen, oradaki!' şeklinde bir seslenişi, seslenilenin bireyin dönme hareketiyle özneye dönüşmesiyle karşılık bulmaktadır (Althusser, 2008). Özne olarak çağrılma, Özne’nin çağrısına tabi olma, öznelerin diğer özneleri ve kendilerini tanımlamalarını sağlayan evrensel tanıma ve uygun davranıldığı müddetçe her şeyin yolunda gideceğine inanılan mutlak güvencenin oluşturduğu dörtlü düzeninin sardığı özneler, koyuldukları yolda kendiliğinde yürümektedirler (Althusser, 2010: 104, 208). Dolayısıyla Althusser'e göre ideoloji tarihin ötesinde ve bilinç dışı işleyiş göstermesiyle özneyi doğmadan sistem içinde konumlandırmaktadır (Zengin, 2018: 54). Tarihin ötesindedir çünkü zihnin işleyiş tarzı tarih boyunca değişmemiştir (Güngör, 2001: 225). Seslenme ve cevap verme sistemin özneden beklentisini ifade ettiği kadar, öznenin de kabul ettiği ve parçası olduğu sistemden beklentisini de göstermektedir. Althusser'in çağırma ve adlandırmadan kast ettiği tam olarak bu sisteme dâhil edilme durumudur. Çağırma süreciyle aynı amacı güden geleneklerin, göreneklerin, bireyler arası ilişkilerin etkisi de eklendiğinde, dışında bulunması çok zor olacak ideolojik bir atmosfer gerçekleşecektir (Kazancl, 2006: 12). Bu aşamada Althusser'in kavramsallaştırdığı şekliyle DİA sistematiğinde incelemek yerinde olacaktır.

\section{Devletin İdeolojik Aygıtları}

Devletin ideolojik aygıtları; sınıfların var oluş koşullarından, mücadele deneyimlerinden ve pratiklerinden doğan ideolojilerin temsil alanlardır (Bank, 2016: 36). Toplumda mevcut bulunan sınıf çatışmaları, kendi hegemonyalarını kurmanın mücadelesi ile çoğunlukla hâkim ideolojilere başvurmaktadırlar. Siyasal yapılar ise muhtemel çatışmaların meydana getireceği dağılmayı önlemek ve örtmek için, hâkim ideolojiyi oluşturur ve toplumu bütünleştirici olduğunu iddia ettikleri fikirler etrafında birleştirmeyi amaçlarlar. Siyasal erk bu amacına ulaşmak için devletin baskı ve ideolojik aygıtlarını devreye sokmaktadır. Bu bağlamda, Marksist gelenek Devlet Aygıtını; zor kullanan bir 
baskı aygitı olarak ifade ederken Althusser, ideolojinin zihin tasarımları olarak belli aygıtlarda gerçekleştiğini belirtir ve Devletin Baskı Aygıtı ve Devletin İdeolojik Aygıtları ayrımını geliştirir (Althusser, 2001: 123).

Althusser'in belirttiği ayrıma göre; hükümet, ordu, polis, mahkeme, hapishane gibi kurumlar Devletin Baskı Aygıtı olarak işlev görmektedir. Bununla birlikte dini, öğrenimsel, hukuki, siyasal, sendikal, kültürel, aile ve haberleşme gibi çok sayıda DİA bulunmaktadır. Baskıcı devlet aygıtları; sömürü ilişkilerinin son çare olduğu aşamada, ideolojinin yeniden üretiminin politik koşullarını meydana getirir. Devlet aygıtı ise; kendisinin yeniden üretimine katkıda bulunmakla kalmaz, aynı zamanda ve her şeyden önce, hegemonik ideolojinin bekası için politik koşulları güvence altına alır $(2010 ; 2014)$. Althusser DİA'ların çok sayıda ve dağınık olduğunu belirtse de egemen ideolojinin şemsiyesi altında birleşik kabul edilmeleri gerektiğini düşünmektedir (Güngör, 2001: 222).

Devletin baskı aygıtıyla ideolojik aygıtları arasındaki temel fark işleyişlerindeki önceliklerinde (baskı ya da ideoloji) kendini göstermektedir. Devletin tek bir baskı aygıtı bulunmasına karşın, birden çok ideolojik aygıtı bulunmaktadır. Baskı aygıtı kamuda yer alırken DİA'ların büyük kısmı özel alanda kendini göstermektedir. Tamamıla baskıya dayanan aygıt yoktur. Devletin baskı aygıtı önceliği zor kullanmaya vermiş olsa da ikincil olarak meşrulaştırıcı ve yeniden üretim sağlayan değerler adı altında ideolojiyi de kullanmaktadır. Aynı zamanda DİA'lar da salt ideolojiyle hareket etmemektedir. Bünyesinde hafifletilmiş hatta simgesel şekilde bile olsa baskı da içermektedirler. (Althusser, 2010: 169-171). Sonuç olarak birey, toplumsal kimliğini kurarken kendini kuşatan ideolojilerin talimatlarına yaslanacaktır. Bu durumda birey gerçekte yaşanan olağan durumla aygitlar aracılığıyla dayatılan arasındaki ayrımı fark edemeyecektir (Sucu, 2012: 34).

Sonuç olarak; tüm DİA'ların ortak hedefinin üretim ilişkilerini ve kapitalist sömürü ilişkilerini yeniden üretmek olduğunu belirtmek yanlış olmayacaktır. $\mathrm{Ne}$ var ki her biri bu hedefi kendine has yöntemlerle yapmaktadır. Haber aygltı yurttaşları kitle iletişim araçları aracılı̆̆ıyla milliyetçilik, şovenizm, ahlakçılık gibi donelerle günlük olarak beslemekteyken, kültürel aygıtı da bu beslenmeye yardım etmektedir. Dinsel aygıt bireye doğum, ölüm, nikâh gibi önemli törenler aracılığıyla yönlendirme yaparken, çocuğun etkiye en açlk olduğu yıllar boyunca, aile aygıtı ve öğrenimsel aygıt egemen ideolojiyle kaplanmış bilimsel dersleri ya da sadece ahlak, felsefe, yurttaşlık eğitimi gibi katıksız egemen ideolojiyi çocukların zihinlerine işlemektedir. Böylece bireyler ilerleyen süreçlerde, eğitim durumlarına ve aile yapılarına göre üretim ilişkileri içinde profesyonel ideologlar olarak yeniden üretimi gerçekleştirmek üzere yerlerini almaktadırlar (Althusser, 2010: 179-180).

İdeolojiyi Althusser'in tanımını yaptığı DİA bağlamında ele aldığımız çalışmamızda buraya kadar; bireyin ideolojiyle çepeçevre kuşatıldığının, devletin 
ideolojik aygıtları aracılığıyla çağrıldığının, belli kültürel formlar içinde özne olarak belirlendiğinin, dolayısıyla kendinden bekleneni gerçekleștirmek üzere kodlandığının tartışmasını yürütmüş olduk. Althusser ideolojiyi; sistemin devamlılığını sağlayan yeniden üretim bağlamında ele aldığı için, alternatif ideolojilerin adlandırma mücadelesine nasıl dâhil olabilecekleri sorusu üzerinde durmamaktadır. Bu tablo karşında bireyin egemen ideolojiden bir kaçış hakkı bulunduğunu bir kez de bu makalede iddia etmek istemekteyiz. Burada ideolojiyle kuşatılmış bireye çözüm önerisi olarak, Gramsci'nin alternatif hegemonya alanlarını ve Hall'un okuma süreçlerini sunma niyeti içerisindeyiz. Bahsi geçen okuma süreçleri; egemen ideolojinin birey tarafından anlamlandırılma safhalarını içermesiyle, hegemonik bir mücadele alanı olarak, bireye egemen ideolojiden kendini gerçekleştirebileceği başka bir ideolojiye geçiş imkânı sunabilen bir paradigma olarak belirmektedir.

\section{Althusser Eleştirisi ve Hegemonik Mücadele Alanı}

Althusserci yaklaşımla ideoloji balığın içinde yaşadığı sudur. Su balığın varlık nedeni olmasıyla ayrılmazıdır ve her yerdir. Balık yalnız suyu bilip suyu tanır ve zanneder ki bütün dünya suyla kaplıdır (Kazancı, 2002: 86). Bu yaklaşımıyla Althusser kuramını, kendini eleştirenlerin üzerinde durduğu şekliyle; ideolojinin dışında ideolojiden başka bir şey olmadığının üzerine kurmaktadır. Toplumsal formasyonun tüm katmanlarına egemen ideolojinin yayılması, öznelere tek öznenin çizdiği sınırlar dâhilinde hareket alanı sunmaktadır. Bireylerin sınırların dışına çıkmamaları için DİA'lar işletilmekte, yetersiz kaldığı alanlar sistemin uyumu ve devamlılığı adına devletin baskı aygıtı tarafından doldurulmaktadır. Böylece DİA'lar ve baskı aygıtının mükemmel uyumuyla sistemin devamlılığı garanti altına alınmış olmaktadır. Sözünü ettiğimiz kurulu sistem bireyin ideolojinin dışına çıkmasını imkânsız değilse de neredeyse olanaksız kılmaktadır (Güler, 2014: 6038).

Gramsci'nin politik toplama diyalektik bir ilişki içinde yerleştirdiği sivil toplum alanına ait olan; özel iletişim araçları, özel okullar, sendikalar, partiler, dernekler ve spor- kültürel kulüpleri gibi özel örgütlerin tamamı (Özgüden, 2015: 38), Althusser tarafından son kertede yönetici ideoloji altında işleyiş göstermeleri nedeniyle devlet yapısı altında bütünleşik kabul edilmektedir (Hall et al., 2014: 200). Oysa Gramsci'nin tartıştığı şekliyle sivil toplum alanı ekonomik, ideolojik ve politik düzeylerin hepsinde ayrı ayrı savaş verilen, hegemonya mücadele alanıdır (Hall et al., 2014: 166). Böylece entelektüel düzeyde yeni hegemonya alanlarının doğma ihtimali her zaman olasıdır.

Gramsci'ye göre hegemonya; toplumsal düzenin gidebileceği belli yönler için rıza kazanmayı gerektirmektedir. Rıza kavramı; çelişki içermeyen homojen bir uzlaşmadan ziyade farklı çıkar ve değerlerin kesiştiği bir yelpaze olarak kullanılmaktadır (Buci-Glucksmann, 2012: 124-126). Rızanın üretimi bir dereceye kadar kültürel bir savaş olduğundan; seçim siyaseti, medya, yardım 
kuruluşları, tüketici grupları, okullar, üniversiteler ve dini gruplar gibi bir dizi toplumsal kurum bu savaşa sahne olmaktadır (Wayne, 2006: 220-222).

Hall; Althusser'i en temel üç konuda eleştirmektedir. Birincisi; Althusser'in ezilen sınıfın ideolojisinin üretimine dair bir yorumda bulunmayışıdır. Oysa hayatın akışı içinde egemenler kadar ezilenler de kendilerine ait ideolojiler edinmekte ve çatışma alanları içinde bunları yeniden üreterek sürdürmektedirler. İkincisi sivil toplumda devletten özerk görece özgür çalışmalar yapan örgütlerin Althusser tarafından hâkimiyet içindeki yapı olarak tanımlanmasıdır. Bu durumda haksızlıkları yazan gazetecilerin bilinçsizce onları belirleyen ideoloji tarafından şekillenmiş olması gerekir. Gerçekte olan ise bu değildir. Hall'un üçüncü eleştirisi ise; Althusser'in özneyi merkezden uzaklaştırarak kullanmasınadır. İdeolojiyi toplumsal kurum ve örgütlerin ritüelindeki pratikler olarak değerlendirmesiyle öznesi olmayan süreçler olarak ele almaktadır. Özne kavramını Lacan'dan aldığı çağırma işleviyle öncelemiştir ancak söz konusu özne yaşayan tarihsel bireyler yerine bilinçdışı ideoloji süreçleri tarafından kurulan söylemin özneleridir. Gerçekte özne 'taşıyıcı ve destekleyici' olduğu kadar özgül ideolojilerin üreticileri de olmaktadır (2005a: 371-375).

Gramsci'nin görüşlerinden etkilenen Hall; bireyin kendi varlık koşullarını değiştirebilme gücüne diğer bir deyişle tercih etme kabiliyetine dikkatleri çekmiştir (Turner, 2016: 110). Hall çalışmalarında çağırma mekanizmasını sorgulayarak; ideolojiyi dillerin, kavramların, imgelerin ve temsillerin yer aldığı zihinsel çerçeveler olarak tanımlamaktadır. Dolayısıyla kitlelerin düşüncelerinin kavranarak akıl yürütme marifetiyle harekete geçirildiklerini ileri sürmektedir (2005b: 25-26). Bu noktada diğer düşünürlerden farklı olarak dikkatleri bireyin okuma sürecine çekmektedir. Okuma süreci bireye sunulan her türlü ideolojik metnin anlamlandırılma işlemini kapsamaktadır. Turner'a göre bu metinler; kültürel ürünleri, toplumsal pratikleri hatta kurumları içermektedir (2016: 105).

Hall; somut koşulların ve söylem deneyimlerinin ortaya çıkardığı hegemonya içinde konumlandırılmış öznenin, kendisini yeniden konumlandırabileceği üzerinden değerlendirmeler yapmaktadır (Rehmann, 2017: 200-202). Buna göre Hall, anlam üzerine verilen hegemonik mücadelede; toplumsal ve kültürel inşa alanına dikkat çekmekte ve bireyin kendine has kod açımının önemi üzerinde durmaktadır (Oğuz, 2014: 132). Kodlama/Kodaçımı çalışmasında Hall, ideoloji ve söylem üzerine yürüttüğümüz çalışmamızın bu aşamasıyla ilgili olarak gönderen-mesaj-alıcı döngüsü içerisinde değerlendirilen mesajın; üretim, dolaşım ve tüketim süreçlerini değerlendirir. Bu çerçevede söylemin düz anlamsal boyutunda ideolojik etkiyi görece sabit olarak ele alırken, yan anlamsal düzeyini önemli bir ideolojik müdahale ve çatışma alanını olarak tanımlar. Özne olarak bireylere seslenen ideolojik söylemlerin, bireyler tarafından aynıyla kabul edilme, çözümlenebilme ya da tamamen reddedebilme şeklinde karşılık bulabileceğini savunmaktadır. Bu kapsamda özneler; ege- 
men ideolojiyi aynıyla benimseyen hâkim-hegemonik okuma gerçekleştirebilecekleri gibi, müzakereci yaklaşımla metnin bazı kısımlarını reddetse de genel tanımlar üzerinde egemen ideoloji ile aynı safta yer almayı da tercih edebileceklerdir. Ancak aynı zamanda tüm düz anlamların ve yan anlamların farkında olarak, alternatif bir referans çerçevesine göre muhalif okuma da gerçekleştirebilecektir. Hall bu yaklaşımıyla özneleri yalnızca düz anlamı görmesi gereken edilgen nesne konumundan kurtararak, söylemin içindeki yan anlamları keşfedebilecek göreli özerkliğiyle yeni anlam üretecek etken rolü üzerinde durmaktadır. Aynı zamanda anlamın üretim sürecine dikkatleri çekerek saydam ve sabit olmadığının altını çizmektedir (Hall, 2006).

Yukarıdaki bilgiler ışığında çalışmanın yönteminde, kavramsal çerçevenin somut örneği olarak, DİA aracılığıyla ideolojik dayatma yaşayan bireylerin, egemen ideolojiye karşılık geliştirecekleri okuma süreçleri üzerinde durulacaktır.

\section{Çalışmanın Amacı ve Yöntemi}

Sinema; etkileme, özdeşleștirme, imrendirme gibi etkileri (Adanır, 2003) sayesinde toplumlar üzerinde kültürel değişime sebep olabilecek bir sanat dalı olarak kitleleri çağırmaktadır. Bu çağrıyı Althusser'in sözünü ettiği çağırmayla özdeșleştirirsek, "Hey sen oradaki! Olaylara bir de kameramın lensinden bak!” seslenişi ile yapmaktadır. Aynı zamanda ülkeler kendi içinde de propaganda aracı olarak sinemayı kullanmakta ve egemen ideolojilerine uygun olarak sinemanın yönlendirici etkisinden faydalanmaktadırlar. Bu bağlamda içeriği üzerine çalışma yürüteceğimiz Persepolis filmi; İran'ı anlatan FransızAmerikan ortak yapımı bir film olması ile hem DİA'nın pratikteki işleyişine tanıklık etme olanağı sağlarken aynı anda bu işleyişi gösteren sinema aracılığıla karşı hegemonya unsurlarının aidiyetleri itibariyle başka bir hegemonya alanı oluşturulması ile dikkate değerdir. Örneğin özgürlük heykelinin iskelet kafası formunda sunulduğu bir duvar resminin önünde, zar zor yürüyen bir motosiklet üstündeki dört çocuklu bir ailenin resmedilişi; hegemonyaya direnişin, bilinen markaya ait bir spor ayakkabı, bir kaset gibi küresel değeri olan temsiller üzerinden gerçekleştirilişi tarafsız gözükmemektedir. Bu yönleriyle Persepolis filminin Batı medeniyetinin Doğu toplumları hakkında düşünce biçimlerini ifade eden "Oryantalizm" ya da diğer adı ile "Şarkiyatçılık" başlığı altında ya da daha geniş kapsamıyla kültürel emperyalizm etrafında incelemek de mümkündür. Ancak ayrı çalışmaların kapsamına girecek bu konular makalenin ana sorunsalından uzaklaşmamak ve sınırlılıklarını göz önünde bulundurmak adına film hakkında yapılacak diğer çalışmalara bırakılmıştır.

Persepolis filminin makale için önemi; devletin ideolojik aygıtlarının yoğun işletildiği önemli bir örneği olmasından, üstelik filmin gerçek bir hayat hikâyesinden yola çıkması ile kurgudan ziyade gündelik yaşamın pratiklerini tar- 
tışma imkânı sunmasından ve olumsuz ele alınan egemen ideolojiye vurgu yapmasından kaynaklanmaktadır.

Doküman incelemesi yoluyla yapılan bu çalışma nitel bir karakter taşımaktadır. Çalışmanın dokümanını Persepolis filmi oluşturmaktadır. Çalışmada örneklem olarak Persepolis filminin seçiminde; çalışmanın kavramsal çerçevesiyle bağlantılı olması nedeniyle, önceden belirlenmiş ölçütleri karşılayan olguların çalışıldığı ölçüt örnekleme yöntemi (Ylldırım \& Şimşek, 2008) benimsenmiştir. Amaç, filmde somutlaştırılan ideoloji ve birey ilişkisinin, yukarıda ileri sürülen veriler ışığında, devletin ideolojik aygıtlarının işleyişleri özelinde değerlendirilmesidir. Diğer bir deyişle incelenen kuramın pratikte işleyişine şahitlik etmektir. Bir filmde sözü geçen aygitların tümünün bulunmaması doğal kabul edilmelidir. Çünkü sunulan verilerin hepsinin bir filmle tümüyle örtüşmesi mümkün olmayacaktır. Bu nedenle, devletin ideolojik aygıtları, film içeriğinin kısıtlılığı göz önünde bulundurularak, inceleme çerçevesi içine dâhil edilecektir.

Sinematografi sanatı, anlamın üretilmesinde ve aktarılmasında kullandığı coğrafyalar üstü görsel üstünlüğüyle, kitleler üstünde büyük etki meydana getirmektedir. Kendine has dil yapısı, izler kitle üzerinde özdeşleşme etkisi ortaya çıarmaktadır. Bununla birlikte, sinemada geçen retorik, imge ve sembollerin işlevlerinin açıklanması; ortalama değerlendirmeye ek olarak, katmanlı anlamlarının da ortaya çıkmasına yardımcı olacaktır (Mencütekin, 2010: 265). Sinema film şeridi ve imgeler aracılığıyla psikolojik ve simgesel anlam taşıyıcısıdır (Adanır, 2013: 53). Bununla beraber anlam; görünenle görünmeyen arasında devam eden ilişkiden doğmaktadır (Wayne, 2011: 164). Dolayısıyla sinema anlamların saklı olduğu bir anlatı sanatı olarak tanımlanabilir.

Diğer bütün biçemler gibi sinema anlatısı da öykü ve söylem olmak üzere iki kısımdan meydana gelmektedir. Öykü; olayları, karakterleri, çevresel özelliklerini kısaca içeriği kapsarken, söylem; olay örgüsü, zaman, kurgu aracılığıyla öykünün anlatılma biçimini ifade etmektedir. Diğer bir deyişle öykü filmin nesini, söylem ise nasılını oluşturmaktadır (Yaktıl, 1995, s. 125). Bu çerçevede irdelenen filmde, hakkında tartışma yürüttüğümüz kavramlara dair temalar oluşturularak, dizinin öykü ve söylem üzerinden incelendiği anlatı yöntemi (narrative method) aracılığıyla analizi yapılacaktır. Anlatı yöntemi, sinemasal anlatı içerisindeki neden sonuç bağlamının nasıl gerçekleştirildiğini göstermesi yönüyle tercih edilmektedir (Taş Öz, 2012: 81). Yazın alanında daha çok kullanılmakla birlikte Manfred Jahn, Jacop Lothe, Seymour Chatman ve Robert Burgoyne gibi araştırmacılar tarafından sinemaya uyarlanan bu metodolojide, sinemasal metindeki anlatı gerçekliğinin (narrative reality) üç yönü; anlatım eyleminin üretildiği anlatım/anlatış unsuru, içeriğin anlatıldığı öykü ve söylemine gönderme yapılan anlatının bizzat kendisi (Sözen, 2008: 578) üzerinden çözümlemeye gidilecektir. 


\section{Bulgular ve Yorumlar}

Çalışmanın bu safhasında IMDB puanı 8.1 olan Persepolis ${ }^{1}$ filmi üzerinden DİA’nın işleyişi ve birey üzerindeki etkileri tartışılacaktır. Öncelikle anlatımın üretildiği anlatış unsuru üzerinde durulacaktır.

Sinemada öykü ve anlatılanlar estetik kurallar çerçevesinde izler kitleye sunulmak üzere yeniden üretilmektedir. Öykünün anlatılışı bir mantığa sahiptir ve sanatçının konuya bakış açısını yansıtmaktadır. İzler kitlenin kendine aktarılanı algılayabilmesi, ancak sözünü ettiğimiz bakış açısını biçimsel-içeriksel düzeyde kavranmasıyla mümkün olmaktadır. Bakış açısını senaryoda, kurguda, dekorda, çerçevelemede ve oyuncu yönetiminde görmek mümkündür (Adanır, 2003: 55-56). İncelediğimiz film bakış açısı yönüyle en eski anlatım biçimlerinden biri olan trajikomik anlatım biçimi içinde yer almaktadır.

Tablo 1. Film Bilgileri

\begin{tabular}{|l|l|}
\hline Filmin Adı & Persepolis \\
\hline Film Afişi & 96 dakika \\
\hline Film Süresi & 2007 \\
\hline Yapım Yılı & Fransızca İngilizce Farsça Almanca \\
\hline Film Dili & Fransa Amerika Birleşik Devletleri \\
\hline Ülke & Vincent Paronnaud, Marjane Satrapi \\
\hline Yönetmen & Marjane Satrapi \\
\hline Senaryo & Kathleen Kennedy \\
\hline Yapımcı & $\begin{array}{l}\text { Chiara Mastroianni Danielle Darrieux Catherine De- } \\
\text { neuve Simon Abkarian }\end{array}$ \\
\hline Oyuncular & \\
\hline
\end{tabular}

1 Persepolis filmi, 2007 Cannes Film Festivali Jüri Özel Ödülü’ne layık görülürken, 2008 yılında Akademi Ödüllerinde En İyi Animasyon Film ödülüne aday gösterilmiştir. Film Cannes Film Festival'inde gösterime girmeden önce İran hükümeti tarafından, aynı zamanda "Film Ekimi”nde Türkiye'nin İran konsolosluğu tarafından yayınlanmaması için girişimlerde bulunulmuştur. Bunlara rağmen film gösterime alınmakla kalmamıș, "2007 Film Ekimi”nde biletleri tükenen ilk film olmuştur. 


\section{Persepolis Filminin Konusu}

Film, Marjane Satrapi'nin kendi yaşamını anlattı̆̆ı aynı ismi taşıyan otobiyografisinden uyarlanmış bir animasyon filmidir. İran'da Şah'ın devrilmesinin ardından, daha demokratik bir ülke kurma hayalleri olan İranlılar, daha da sinırlandırılan özgürlükler ve kötüye giden yaşam koşulları içinde kendini bulmuştur. Dolayısıyla film çoğunlukla devrimin getirdikleriyle değil götürdükleriyle dikkati çekmektedir. Bu ortamda çocukluğunu geçiren Satrapi ergenliğini, dikkat çekici fevri tavırlarının zararlarından korunması için ailesi tarafından gönderildiği, özgürlüklerle dolu Avusturya'nın Viyana şehrinde yalnız başına geçirecektir. Avrupa, Satrapi'yi sınırsız bir özgürlükle karşılamış gibi gözükse de, Satrapi'nin kültüründen gelen ve terk edemediği aitlik hissi, daha çok yalnızlaşmasına sebep olur. Ülkesini ve ailesini özleyen Satrapi, aşk acısının ve geçirdiği ağır hastalığın verdiği duygusallıkla İran'a dönmeye karar verir. Ancak İran'da işler bıraktığından da karmaşık bir hal almıştır. Doğu ve Batı arasındaki uçurumda, birbirinden çok farklı ideolojilere kendince okuma geliştiren Satrapi, aidiyet duygusunun yokluğunda yaşadığı karmaşa ve kaygı nedeniyle hiçbir yerde mutlu olamamaktadır.

Film; İran'da devrilen Şah döneminin son günlerini, İslam Devrimini ve Irak-İran Savaşı'nı, aynı dönemde Avrupa'nın bireylere sağladığı sınırları belirsiz, faydası ve zararı tartışmalı özgürlük ortamını konu almasıyla, tarihsel geçişlerin ve sosyo-politik yönüyle farklı ülkelerin, Satrapi özelinde, bireylerde meydana getirdiği etkilerini, trajikomik yaklaşımıyla, gözler önüne sermektedir.

\section{Persepolis Filminin İncelenmesi}

Filmin adının Persepolis olması; bir zamanlar Perslerin başkenti olarak, söz konusu toprakların dünyanın en ileri medeniyetlerinden birine sahiplik ettiğine yapılan vurgu nedeniyledir. Filmin gerçek coğrafyada gerçek insanlarla çekilmeyip bir animasyon halinde çekilmesindeki amaç, oluşabilecek stereotiplerden ya da karakter oyuncu uyumsuzluklarından uzak durarak, izler kitle üzerinde 'Bu ben olabilirdim' hissini verecek özdeşleşmenin sekteye uğrayabileceği durumlardan kaçınmaktır. Şimdiki zamanın renkli, geçmiş zamanın buhranlı halini yansitacak şekilde siyah beyaz oluşturulan film, flashback (geriye dönüş) kurgusuyla geçmişle bugün arasında köprü kurarak, hayat hikâyesini senaryo olmaktan çıkarmakta ve yaşandığı gerçeğini gözler önüne sermektedir. Özellikle Satrapi'nin dış ses olarak konuyu anlatırken takındığı yoğun mizahi yaklaşım ve destekleyen ses efektleri (sesleme) izler kitleye insani bir dokunuş sunarak onların filmle duygusal bağ kurması sağlamaktadır. Bununla birlikte olayların, yoğun baskıların yaşandığı ve korku atmosferinin yaygın olduğu savaş ortamında gerçekleștiği düşünülünce, yaşanan dehşet izler kitle tarafından daha net hissedilebilmektedir.

Persepolis otobiyografik bir film olmasıyla yazarının eser üzerindeki etkisi ve amacı da önem taşımaktadır. Filmin yönetmeni Vincent Paronnaud ile ya- 
pılan röportajda yönetmen Satrapi'yi; insanlara medyada gördüklerinin dışında farklı bir bakış açısı kazandırmaya çalışan, belli bir entelektüel amaçta 'kavgaya öncülük eden' tarihi olaylar etrafında savaş, sürgün gibi gerçekliklere dikkat çekmeye çalışan, otobiyografi yazarı olarak oldukça alçakgönüllü ve özverili biri olarak tanımlamaktadır (Lavoıgnat, 2007). Satrapi, hayatının biçimlendirici deneyimlerini içeren çocukluk, ergenlik ve erken yetişkinlik yıllarını açıklık, mizah, keskinlik ve duygusallıkla harmanlayarak seyirciyle buluşturmaktadır. Film, yapısı itibariyle siyasi bir çağrı veya tarihi bir belge değil; daha geniş sonuçları olan açıkça kişisel bir vizyonu temsil etmektedir (Warren, 2010: 117, 122). Satrapi filmi yapmaktaki bir amacının da Batılıların İran'a yönelik fundamentalist algısını yıkmak olarak görmekte ve Batılı izleyicileri de eleştirecekleri İranlılar gibi 'köktenci' olmamaya davet etmektedir (Balaban, 2016: 375).

Çalışmada, teoride üzerinde durulan temeller ve çalışmanın amacı doğrultusunda anlamlı bulunan sahneler incelenmiştir. İlgili sahneler ile ilgili olarak DİA'lar çerçevesinde çözümleme yapılacaktır. Bu DİA'lar yukarıda tartıştığımız kavramsal çerçeveye de uygun olacak şekilde; Aile DİA'sı, Öğrenimsel DİA, Kültürel DİA, Dinsel DİA ve Haberleşme DİA'sıdır.

\section{Aile DİA'sı}

İdeolojik aygıtlarından bazıları diğerlerine göre daha başat konumdadır. Bu konumu aygıtın ait olduğu yapının, ideolojiyi doğallaştırma işleyişine borçludur. Hatta kimi zaman yaygın paylaşılmasıyla ve temel değerlerden sayılmasıyla ideolojiyi öylesine doğal gösterir ki; sunulan ideoloji evrensel hatta tıpkı doğanın kendisi gibi değiştirilemez ve sorgulanamaz kabul edilecektir (Fiske, 2003: 233). Aile bu konuda başı çekmektedir.

Filmde; okulda şahı sevmeyi öğrenen Satrapi, babasının okullarda öğretilenlerin yerine gerçekleri kendisinden dinlemesini söyleyerek anlattıklarıyla, bundan vazgeçmektedir ki; bu durum aile aygıtının öğrenimsel aygitın da önüne geçerek en etkili DİA olduğunun kanıtıdır. Kendini kucağında güvende hissettiği ve hep yanında olduğunu bildiği ailesi; bütün yanıltmalardan uzak bir doğrunun merkezini oluşturmakta ve Satrapi'nin hayal dünyasında büyük köşe taşlarını belirlemektedir. Ailesinin inançlarına yapılan haksızlığın kendisine yapıldığını kabul eden Satrapi, arkadaş çevresindeki işleyişi bu öğretilere göre düzenlemektedir. Bunu yaparken başvurduğu aşırılıklardan yine ailesinin müdahalesiyle geri dönmektedir. Satrapi gibi arkadaşları da, ailelerinin ideolojileri üzerinde zihin dünyası geliştirmekte ve taraflarını seçmektedir. Satrapi'nin işkence üzerine oyun kurabilmesi ve arkadaşının babasının insan öldürmesine 'komünist olmak' gibi soyut sebeplerle kendince meşruluk katabilmesi; masumiyet özelliği olan çocukların dönüşümü üzerinde aile aygıtının etkisinin kanıtları olarak karşımızda durmaktadır. 
Amcası yaşanılanların aktarıcısı ve devamlılığın sağlayıcısı olarak yeğeninin hafızasına ihtiyaç duymaktadır. Amcasının, Satrapi'yi hapishane ortamında yaşadıklarına şahit tutarak, inançlarını sevgiyle aktarması; Satrapi'nin sahip olduğu aile ideolojisini güçlendirmektedir. Annesi; okulda karşı çıktıklarıyla sürekli problem yaşayan Satrapi'ye, bakirelerin idam edilmesinin yasak olduğunu bunun için önce devrim muhafızlarıyla zorla evlendirilerek bekâretlerinin alındığını ve öyle idam edildiklerini söyler. Satrapi güven hissinin kaynağı olan ailesinin korkularına da ortak olduğunda, tek başına kültürüne çok yabancı bir ülkeye gitmek gibi büyük kararlar almak zorunda kalır. Viyana'ya gidecek olan Satrapi'ye, büyükannesi, intikam ve sertliğin kötülüğüne, saygınlık ve dürüstlüğün erdemine dair; babası ise kim olduğunu ve nerden geldiğini unutmamasına yönelik tavsiyelerde bulunur. Satrapi ailesinin tavsiyelerini yol gösterici işaretler olarak kabul edecek, hataların tespitini ve çıkış yollarını kendine verilen tavsiyeler ışığında gerçekleştirecektir. İran'a döndüğünde ise, yokluğunda yaşananların iç yüzünü ve yapılan propagandaların arka planını yine babasının anlatımıyla öğrenecek ve buna yönelik tavır geliştirecektir. Aile aygıtının meydana getirdiği bağ öylesine kuvvetlidir ki; Satrapi yaşadığı ayrılığı özgürlüğü için ödediği bedel olarak nitelendirmektedir.

Sonuç olarak; her bireyin öncelikle toplumsallaşmanın ilk çekirdeği olan ailede ideolojik şekillenmeye maruz kaldığını belirtmek hatalı olamayacaktır. Ayrıca ideolojik şekillenme, bireyin özellikle küçük yaşlarda fiziksel ve duygusal bağının en kuvvetli olduğu dönemdeki iletişimini içermesi kadar; gün içinde zamanı en çok aile içinde geçirmesi nedeniyle ve bireyin kendini en rahat ifade ettiği doğal ortamı olmasıyla da yerinde görünmektedir. Aile aygıtı Satrapi için hayatına yön vermesine izin vereceği kurucu ideolojinin kaynağı olmuştur.

\section{Öğrenimsel DíA (Okul DİA'sı)}

Filmin farklı sahnelerinde; okulda olması gereken bilimsel ve tarafsız yaklaşımın aksine, yöneticinin Tanrı tarafından seçildiğini öğretebilecek kadar egemen hegemonyanın işletildiği bir yaklaşım sergilendiği görülmektedir. Çocuklar, küçük yaştan itibaren, kendilerini yönetenlere sevgi ve itaat beslemeleri konusunda yönlendirilmektedir. Okul DİA’sının muhatapları öğrenciler; muhalif bir ideolojiye sahip bir DİA'nın etkisine girmedikçe kendilerine sunulan ideolojiyi kabullenmektedir. Okul, başörtüsü örtmenin gerekçelerinin kabul ettirildiği, kurulan yeni düzenin meşrulaştırıldığı, bu uğurda hayatını kaybedenlerin resmî törenlerle şehit ilan edilerek yası tutulmaya mecbur bırakıldığı resmî kurumlar olarak, egemen ideolojiyi benimsetme görevi üstlenmektedir. Öyle ki din öğretmeni bile, sunmak zorunda hissettiği ideoloji uğruna, öğretmekle mükellef olduğu dini yaklaşımın yakınından geçemeyecek yalan gibi bir argümanla, gerçeklerden çok farklı bir tablo çizebilmektedir. Aynı zamanda sanat gibi evrensel değerler üzerine kurulu bir öğretinin, ideolojiler uğruna sansüre uğrayarak tahrip edilebileceği görülmektedir. Zorunlu yapı- 
lan toplantılar manevi değerler sömürüsü üzerinden günlük yaşamın inşasını gerçekleștirmeye çalışmaktadır. Bu bağlamda, Shoemaker \& Reese yönetici sınıfın egemenliğini bir dizi ortak duyusal değer ve mekanizma aracllığıyla sürdürdüğünden bahsetmektedir. Söz konusu ortak işleyiş, sınıfların kendi rızalarıyla tahakküm altına alınmasını ve ideolojinin meşrulaşarak yeniden üretilmesini gerçekleştirecektir (2014: 112). İdeolojik aygit olarak okul tam olarak bu mekanizma çerçevesinde işlerlik göstermektedir.

Sonuç olarak; okul evrensel değerler kazandıran, eleștirel düşünceye hâkim, bilimsel veriler üzerine kritik yapabilecek öğrenciler yetiştiren bir eğitim yuvası olmaktan ziyade; istenen, öngörülebilen ve yönlendirilebilen halk inşasında, standart düşünce ve kalıp yargılar üreten bir görev üstlenmektedir. Ancak Satrapi karakteri, aile aygıtının da etkisiyle, temel aldığı ideolojiye uygun olmayan görüşlere, eleştirel ya da muhalif okuma gerçekleştirmektedir.

\section{Kültürel DİA}

İdeoloji toplum düzeninde bir bütün olarak değil gruplar arası düzeyde anlam taşımaktadır. Çünkü ortada mücadele edilmesi gereken bir amaç, çıkar çatışması, kaynaklar üzerinde bir rekabet olmalıdır ki; bir ideolojiye ait olmak önem kazanabilsin (Van Dijk, 2015: 46-47). Kültürel işleyiş egemen ideolojinin hegemonya savaşı ile gruplara ait ideolojilerin kendince direnişleri arasında gerçekleşmektedir. Filmde söz konusu çatışma açık bir biçimde gözlemlenebilmektedir.

Filmde şahın devrilmesiyle herkes kendini devrimci ilan eder. Şah hayranları bir anda şah düşmanına dönüşürken, politik toplantılarla dünün düşmanları ulusal kahramanlara dönüşür. Dolayısıyla kültürel yapıdaki egemen ideoloji değişimi; bireylerin düşünce yapılarını değişime uğratarak, sosyo-politik duruşlarını değiştirmelerine, dost düşman algılarını yeniden biçimlendirmelerine sebep olmaktadır. Diğer bir deyişle kültürel yapı, genel olarak bireylerin toplum içindeki pozisyonlarını yönlendirmektedir. Bina duvarlarında görülen; askerliği kutsal görev, Batı'yı düşman, şehitliği tarihin kalbi olarak gösteren duvar resimleri hükümet tarafından halk üzerinde meydana getirmek istediği tesiri elde etmek için propaganda amaçlı kullanılmaktadır. Bu çizimler hükümetin Amerika başta olmak üzere Batı'ya karşı olan politik tepkilerini yansıtmakta ve kamuoyunu yönlendirme görevi üstlenmektedir. Böylece kültürel aygıt haberdar etme ve standart belirleme işlevi görmektedir.

Aynı zamanda filmde, sokaklarda gezen tanklar, heykellerin sökülmesi gibi toplumun çatışma içinde olduğunu ya da direndiğini gösteren sahneler bulunmaktadır. Bu göstergelerle halk üzerinde kabullenme etkisi meydana getirilmek istenmektedir. Hükümet ne kadar büyük baskılarla yasaklamaya çalışsa da dönüşen kültüre muhalif kalabilenler, küresel egemen kültürün temsillerini ülke içinde yaşatmaya devam etmektedir. Satrapi de onlardan biridir. Karaborsadan yasaklı bir kaset satın aldığı sırada iki çarşaflı kadın tarafından, 
markalı ayakkabı ile üstünde 'punk ölmedi' yazan ceket giydiği ve Michael Jackson yazan rozet taktığı için punkçu ve yoz olmakla suçlanır.2 Hükümetin kaset, rozet, spor ayakkabı gibi basit nesnelere karşı takındığı yasaklayıcı tavır; kabul ettirmek istediği değerlerin, söz konusu göstergelerin aksi değerleri temsil ettiğini düşünmesinden kaynaklanmaktadır. Ailesi tarafından Viyana'ya gönderilen Satrapi, önce karşılaştığı özgürlükten hoşnut, kendini yerini bulduğuna inandırmaya çalışsa da, farklı kültürlerin etkisinde hiçbir yere ait olamaz ve sürekli yer değiștirir. Avrupa'da Ortadoğulu olmanın, söylediği kişide meydana getirdiği tepki o kadar büyüktür ki; ortamdan etkilenen Satrapi, bir sahnede nereli olduğuna dair yalan söyleyerek aitliğini yok saymıştır. Memleketine geri döndügünde Avrupa hakkında büyük hayalleri olan İranlllar Satrapi'ye yoğun ilgi göstererek, duymak istediklerini anlatmasını isterler ancak; Satrapi gibi onlar da aradıklarını bulamazlar. Her ne kadar kendi kültürleri aksini iddia etse de, halkın özgürlük özleminin oluşturduğu Batı hayranlığının önüne geçilemediği görülmektedir. Sevgilisiyle ele ele tutuşurken devrim muhafızlarına yakalanan Satrapi'yi kurtaran babası, kendi gençliklerinde bunu yapabildiklerine ve ülkenin değişimine dikkat çeker. Bugün yasak olan olguların geçmişte özgürce yaşandığına yapılan vurgu; kültürel dönüşümünün halkın yaşam standartlarını ve algılarını nasıl değiştirdiğini göstermekle, kültürel aygıtın hayat tarzı belirleme etkisi üzerinde durmaktadır.

Sonuç olarak; incelenen sahnelerde giydikleri spor ayakkabılarının markalarından, dinledikleri müziklere, halkın üzerinde küresel kültürün etkileri fark edilmektedir. Hatta Satrapi'nin film boyunca ayağında görülen markalı ayakkabı onun mevcut kültürel aygıta karşı duruşunun da sembollerinden biri olarak dikkati çekmektedir. Kültürel yapının dönüşümü, eskiden yaygın kullanılan ve sorun kabul edilmeyen durumların etiketleme ve yasaklama sonucu ceza sebebi olmasına yol açtığı görülmektedir. Dönüşüm için kurallar son derce katı ve korku atmosferinde uygulanmaktadır ki; muhalif seslere ve sorgulamalara yaşam hakkı tanınmamış olsun. İnsanlar sürekli diğer insanlar tarafından şikâyet edilerek dışlanma ve cezalandırılma korkusu içinde yaşadıklarından, ifade özgürlüklerini kullanmayı terk etmeyi yeğlemekte, dolayısıyla tepkisizliği içselleştirmektedir. Ancak egemen kültürel ideolojiye muhalif okuma geliştirenler, doğru olduklarına inandıkları şeyleri, bedelini göze alarak gizli saklı yollardan yapmaktadır. Kültürel aygıtın işlevini ülke bazında gösterdiği söylenecekse de; film genel olarak Satrapi ve ailesinin gözünden anlatıldığından birey bazında etkisi yadsınamasa da tam olarak gerçekleştiremediği görülmektedir.

2 Punk kültürü, 1970’lerin ortasında ifade özgürlüğü hareketi ve isyanı olarak ortaya çıkan, sistem karşıtı görülen Rock müziğe dayalı, kendi giyim tarzı, felsefesi, edebiyatı ve dansları olan bir alt kültürdür. 


\section{Dinsel DíA}

Film boyunca dinsel aygıt egemen ideolojinin eril tahakkümü için kullanılmaktadır. Kadınların hayat tarzı; dinin gereği, şehitlere gösterilmesi gereken hürmet, cehennemden kurtulmasının yolu gibi dini gerekçelerle şekillendirilmeye çalışılmaktadır. Yapılması gerekenler kadınlara özel ve en çok onlar içindir. Erkeklerin cinsel dürtülere maruz kalmaması için kadınların sakınması üzerine kurulan ilişkilerde erkekler, uyaran ve denetleyen rol üstlenmektedir. Örneğin erkekler için sakal zorunluluk değilken kadın için başörtüsü zorunluluktur. Erkekler istediği darlıktaki kıyafetleri istedikleri oturuş şekillerinde giyebilirken, kadınlar dar giymemeli ve sokakta koşmamalıdır. Diğer bir deyişle kadınlar erkeklerin kendilerinden etkilenebilecekleri hareketlerden uzak durmalıdır. Erkeklerin ise kadınların kendilerinden etkilenmesi konusunda endişelenmelerine gerek bile yoktur. Dolayısıyla "Yönetici bloğun hegemonyası, basitçe politik düzeyde değil, sosyal yaşantı ve düşünüşün her yönünü etkileyen bir şey olarak görülmelidir" (Hall vd., et al., 2014: 170).

Satrapi'nin dine yaklaşımının ise filmin seyri içinde değiştiği görülmektedir. Çocukluğunda, dini, daha yaşanılabilir bir dünya inşası için, kuralları olan yönetim şekli olarak tarif etmektedir. Kendisini son peygamber olacağına inanan Satrapi, herkesin; iyi huylu olmak, güzel kelimeler kullanmak, iyilik yapmak gibi zorunlulukları olan, içinde fakirlerin günde bir kez kızarmış tavuk yiyebileceği, yaşlı kadınların acı çekmeyeceği bir kurallar listesi açıklar. Hedeflerine ulaşmak için yasaklama yöntemi benimsemeyi öngörmektedir. $\mathrm{Bu}$ yaklaşımla dinin Satrapi üzerinde, mutluluğa ve adalete dayalı kuralcı ve yasaklayıcı bir algıya sebep olduğu anlaşılmaktadır.

Satrapi kendi doğrularıyla çatıştığı dönemlerde Tanrı'yla konuşmalar gerçekleștirmektedir. Dolayısıyla her fiilin arkasında denetleyen ve yöneten bir güç olarak Tanrı'nın varlığını kabul etmekte olduğu görülmektedir. Hayalinde Tanrı merhametli, bilge ve müşfik aksakallı bir dede şeklinde tezahür etmektedir ki; öğretileri de bu yöndedir. Gerçekleştirdiği hayali konuşmalar neticesinde Satrapi yanlış davranıştan vazgeçerek doğru olanı yapmak üzere eyleme geçmektedir. İlerleyen sahnelerde amcasının yaşadıklarından çok etkilenen Satrapi, Tanrı'yı olaylara müdahale etmediği için suçlar ve kendince O’nunla görüșmeyi keser. Filmin kırılma noktası olan bu sahne, Satrapi'nin din algısının zayıflamasına ve tersine bir tutum takınmasına sebep gösterilmektedir.

Yaşanan travmalar, yozlaşmalar, bağnaz tutumlar, yoğun baskı ve zorlamalar ile birleşince zoraki ve isteksiz yaşanan bir din algısı dikkati çekmektedir. Satrapi'nin annesinin arkadaşı, oğluna bir anahtar verildiğini, cepheye gidip şehit olursa, o anahtarla cennetin kapısını açabileceğini, orda kendisini kadınların ve yiyeceklerin karşılayacağını öğrettiklerini söyler. Dolayısıyla dinsel aygıtın cepheye asker kazanmak, bu yolda ölenleri yüceltmek gibi yönlendirici etkileri olduğu görülmektedir. Bunu yaparken bireylerin değerleri 
kadar; karşı cinsiyet, yemek, cennet gibi zaaflarından da yararlanılmaktadır. Her fırsatta şehitlik propagandası yapılmaktadır. Çünkü rejimin önceliği iç politikada yapılanları meşrulaştırmayı yeniden üretmek ve iktidarlarını fedailer kazanarak sağlamlaştırmaktır. Kalp krizi geçiren komşularının eşine hastane idarecisi, hastanın ameliyat olması için yurt dışına çıkarken gerekli olan onayı veremeyeceğini, Allah isterse hastanın düzeleceğini söyler. Dini argümanların kullanıldığı bir yaklaşımla, bireylerin kaderlerine boyun eğmeye zorlandığı görülmektedir. Bir hastane sorumlusu olarak; görevi hastaların sağlığı için gerekeni yapmak olmalıyken dinsel aygıtın etkisiyle üzerine düşeni yapmadan sorumluluktan kaçındığı görülmektedir. Sakal bırakıp, takım elbise giymesiyle bir cam temizleyicisinin hastane idarecisi olabildiği bu sahnede izler kitle, egemen ideolojiye itaat edenlerin her kademedeki yönetimde liyakatine bakılmaksızın yer alabileceğini görmektedir. Bu durumda ideolojik itaat bireylere, bir sınıf aidiyeti verebildiği gibi; emek göstermesine gerek kalmaksızın yeni bir kariyer ve bu kariyerin gerektirdiği sorumluluğu taşımama lüksünü de verebilmektedir. Bütün bunlara rağmen, Satrapi'nin intihara kalkışacak kadar yaşadığı büyük buhrandan onu kurtaran şeyin din ve aile algısının birleșimi olduğu görülmektedir. Tanrı'yı amcasıyla birlikte hayal etmesi, amcasının ölümüyle görülen kırılmanın hayali bir uzlaşmayla onarıldığını resmetmektedir.

Sonuç olarak; dinsel aygit ülke bazında kurumların işleyişine, bireylerin hayat tarzına hatta ülke politikasına yön verecek kadar etkili görünmektedir. Ancak Satrapi'nin genel dini ideolojiden farklı bir dini algıya sahip olması, dinin, onun yaşam pratikleri üzerinde çok etkili olmadığını göstermektedir. Bununla birlikte Satrapi üzerinde dinin işleyişinin; hayatında zor dönemler yaşadığı, ikilemde kaldığı ve çıkış aradığı durumlarda etkili olduğu söylenebilir.

\section{Haberleşme DíA'sı}

Filmde, haberleşme aygıtı kısıtlı yer almakla birlikte propaganda görevi üstlenmiş durumdadır. İktidar sahipleri, eylemlerinin meşrulaştırıcı gerekçelerini kitle iletişim araçları aracılığıyla toplum vicdanına ulaştırmaktadır. Bununla birlikte itaat edilmesi beklenilen kurallar ve etmeyenlerin cezalandırlma hikâyeleri, aynı yöntemlerle bireylere duyurulmaktadır. Şehitlik, askerlik, vatan borcu, millet sevgisi gibi toplumun hassasiyet gösterdikleri kavramlarla manevi duygular sömürülerek, itaat içselleştirilmektedir.

Söylemsel alan toplumsal etkilerin inşa edildiği alandır. Dil, temsil ve anlam üzerinde iletişim pratikleri gerçekleşmektedir. Anlamın üretilmesi ve dönüştürülmesi; sağduyuyu, toplumsala ilişkin gündelik bilgiyi ve tahakküm kurma ve tabi olmaya dayanan iktidar oyununu düzenlemektedir (Hall, 2014: 92). Bu yönüyle filmde haberleşme aygitı toplum üzerinde anlam ve etki üretme, haberdar etme, yönlendirme ve manipüle etme işlevi görmektedir. 


\section{Sonuç ve Değerlendirme}

Althusser'in ideolojiyi pratiklerde somutlaştırılmış temsil sistemleri olarak ele alması, ideolojilerin tekil fikirler halinde değil, ortak kavramlar repertuarına dayanan yan anlam ve mitler içeren söylemsel zincirler halinde işleyiş göstermesi nedeniyledir. Bu çerçevede, ideoloji ve söylemin uysal ilişkisinden doğan hegemonya; hem egemen iktidarın toplum üzerinde baskı aygıtını işletmesiyle oluşmakta hem de beraberinde toplumun rızasının da kazanıldığı bir yapı olarak ortaya çıkmaktadır. Chomsky ve Herman'ın (1995) rızanın imalatı yaklaşımına benzer bir biçimde, egemenlerin çıkarı, toplumun çıkarı olarak kabul ettirilerek, söz konusu çıkarların yaygın kabulü sağlanmaktadır. Toplumun kendilerine sunulan başat ideolojileri meşru olarak kabul etmesi sonucu, bireylerin istenilen davranış ve duygusal kalıplara gönüllü katılımıyla rıza üretilmiş olur. İçselleştirilerek kültür formunda idealize edilen egemen ideoloji, genel geçer değerler olarak her bir birey tarafından onaylanmaktadır.

Anlatı yönteminden (narrative method) yola çıkılarak irdelenen Persepolis filminde, devletin ideolojik aygıtlarının egemen güçler tarafından bir araya getirildiği ve aynı egemen ideoloji formunun birçok aygıt aracılığıyla sürekli işlendiği görülmektedir. Böylece birey ideolojik bir kuşatmanın ortasında bırakılmıştır. Alternatif bir referansı baz alarak, egemen ideolojiden farklı bir ideolojiyi kabul edecek bireyin, olușturulan ortak duyunun güvenli sahasından çıkması için karşılaşması olası olan riskleri göze alması gerekmektedir. $\mathrm{Bu}$ durum hegemonyanın derecesine göre zorluk içermektedir. Bununla birlikte, Persepolis'te gözlemleneceği üzere egemen ideolojiye muhalif okuma geliştiren Satrapi; Althusser'in ele aldığı şekliyle, balığın içinde yaşadığı suyun dışında da yaşam olabileceğini gözler önüne sermektedir. Dolayısıyla Hall'un sözünü ettiği şekliyle bireylere sunulan ideolojik mesajlar egemen ideolojiyle okunabileceği gibi müzakereci ya da muhalif okuma şekliyle de bireyler üzerinde etki etmektedir. Bununla birlikte, yaygın olarak egemen okuma gerçekleștiren bir toplumda, tersi ya da muhalif ve bazen sadece farklı bir okuma geliştirmek korku atmosferinde büyük risklerle karşı karşıya kalma anlamı taşıyacaktır. Elinizdeki çalışmada değerlendirilen Persepolis filmi ya da diğer bir deyişle, Marjane Satrapi'nin yaşanmış hikâyesi, konunun somut örneği olarak karşımızda durmaktadır.

Filmin olumsuz ideolojik yapısına uygun olarak Althusser'in değerlendirmelerinin bir doğrulamasını yapmanın mümkün olup olmadığı incelenmiștir. Sonuçta ortaya çıkan egemen sınıfın her türlü ideolojik aygıtla yaygınlaştırmaya çalıştığı ideolojisine rağmen pratikte görülen direnişler ise; alternatif ideolojilere ait egemenlikleri de ifade edebilecek olan Gramsci'nin detaylandırdığı hegemonya- karşı hegemonya anlayışını ve Hall'un tahakkümü yapılan ideolojilere yönelik bireye sunduğu okuma edimlerini işaret etmektedir.

Söz konusu çerçevede, Gramsci'nin karşı-hegemonyasından yola çıkarsak (Bates, 1975: 352) toplumsal değişim her zaman olası kabul edilmelidir. Do- 
layısıyla, filme ait değerlendirmenin çıktısı; hegemonyasını kurmayı başarmış bir ideolojiye itaat etmemenin, büyük bedeller ödemeyi göze almayı da gerektirse, imkânsız olmadığı ve pratikte alternatif hegemonyaların da işleyiş gösterdiğidir.

\section{Kaynakça}

Adanır, O. (2003). Sinemada anlam ve anlatım. (2. Baskı). İstanbul: Alfa Basım Yayım Dağıtım.

Adorno, T. (2002). The Culture Industry: Selected Essays on Mass Culture. London: Routledge.

Althusser, L. (2001). Lenin and Philosophy and Other Essays. New York: Monthly Review Press.

Althusser, L. (2002). Marx için. (çev. Ișık Ergüden). İstanbul: İthaki Yayınları.

Althusser, L. (2008). On Ideology (Radical Thinkers). New York: Verso.

Althusser, L. (2010). Ídeoloji ve devletin ideolojik aygıtları. Çev. Alp Tümertekin, (4. Baskı). İstanbul: İthaki Yayınları.

Althusser, L. (2014.). On the reproduction of capitalism: ldeology and ldeological state apparatuses. New York: Verso.

Bank, B. (2016). Althusser'in Düşüncesinde Toplum ve İdeoloji. Amme Idaresi Dergisi, 49(2), 1- 38.

Bates, T. R. (1975). Gramsci and the Theory of Hegemony. Journal of the History of Ideas, 36(2), 351-366.

Buci-Glucksmann, C. (2012). Hegemonya ve Riza: Politik Bir Strateji. A. Showstack Sassoon (Der.) Gramsci'ye Farklı Yaklaşımlar (ss. 121-133). Ankara: Dipnot Yayınları.

Chomsky, N. \& Herman, E. (1995). Manufacturing Consent: The Political Economy of the Mass Media. London: Vintage.

Eagleton, T. (2011). Marx neden haklıydı. Çev. Oya Köymen. İstanbul: Yordam Yayınları.

Fiske, J. (2003). İletişim çalışmalarına giriş. Çev. Süleyman İrvan. (2. Basım). Ankara: Bilim ve Sanat Yayınları.

Gramsci, A. (2016). Hapishane Defterleri. Çev. Aycan Özüpek, Ankara: Dorlion Yayınları.

Güler, N. (2014). İletişim, toplumsal cinsiyet ve ideoloji. Journal of Yasar University, 9(34), 6023-6043.

Güngör, S. (2001). Althusser'de İdeoloji Kavramı. Süleyman Demirel Üniversitesi İktisadi ve Ídari Bilimler Fakültesi Dergisi, 6(2), 221- 231.

Gürçınar, P. (2015). Althusser ve Marks'ın ideoloji kavramlarının karşılaştırılmaS1. Journal of International Social Research, 8(41), 449- 457.

Hall, S. (2005a). Anlamlandırma, Temsil, İdeoloji: Althusser ve Post-yapısalcı Tartışmalar. Kitle İletişim Kuramları (ss. 359- 394). Der. ve Çev. Erol Mutlu. Ankara: Ütopya Yayınevi. 
Hall, S. (2005b). The problem of ideology: Marxism without guarantees. Stuart Hall: Critical Dialogues in Cultural Studies (ss. 24- 45). Londra: Routledge.

Hall, S. (2006). Encoding/decoding. Media and cultural studies: keyworks. UK: Blackwell.

Hall, S. (2008). Essential Essays: Foundations of Cultural Studies \& Identity and Diaspo$r a$. Durham: Duke University Press Books.

Hall, S. (2014). İdeoloji ve iletişim kuramı". Medya kültür siyaset içinde (ss.79- 96). (3. Baskı) Haz. Süleyman İrvan. Ankara: Pharmakon Yayınevi.

Hall, S., Lumley, B., \& McLennan, G. (2014). Politika ve ideoloji: Gramsci. Ídeoloji üzerine eleștirel ideoloji analizler (ss. 161-226). Der. ve Çev. Can Şahan. İstanbul: Pales Yayıncılık.

Kazancı, M. (2002). Althusser, ideoloji ve iletişimin dayanılmaz ağırlığı. Ankara Üniversitesi SBF Dergisi, 57(01), 55- 87.

Kazancı, M. (2006). Althusser, ideoloji ve ideolojiyle ilgili son söz. İstanbul Üniversitesi İletişim Fakültesi Hakemli Dergisi, (24), 1- 20.

Lavoıgnat, J., (2007). The Filmmakers talk about PERSEPOLIS, Interviews with CoWriter and Directors Marjane Satrapi, Vincent Paronnaud, Art Director Marc Jousset, and Composer Olivier Bernet: http://www. payvand.com/news/07/dec/1296. html, [06.09.2019].

Mencütekin, M. (2010). Sinema dili, film retoriği ve imgelenen anlama ulaşma. Öneri Dergisi, 9 (34), 259-266.

Oğuz, H. S. (2014). Stuart Hall.... Moment Dergisi, 1(1), 125- 136.

Özgüden, M. (2015). Hegemonya ve Politik Toplum. Ankara: Phoenix Yayıncılık.

Rehmann, J. (2017). Ídeoloji kuramları yabancılaşma ve boyun eğme güçleri. Çev. Şükrü Alpagut. İstanbul: Yordam Kitap Yayıncılık.

Satrapi, M. \& Paronnaud, V. (2007). Persepolis. Catherine Deneu, Chiara Mastroianni ve diğer. DVD. Diaphana Films.

Shoemaker, P. \& Reese, S. D. (2014). İdeolojinin medya içeriği üzerindeki etkisi. Süleyman İrvan (Haz.) Medya kültür siyaset (ss. 97- 132) (3. Baskı). Ankara: Pharmakon Yayınevi.

Sucu, İ. (2012). Althusser'in Gözünden İdeoloji Ve İdeolojinin Bir Taşıyıcısı Olarak Yeni Medya. Selçuk İletişim Dergisi 7 (3), 30- 41.

Sözen, M. (2008). “Sinemasal anlatıda bakış açısı kavramı ve örnek çözümlemeler”. Selçuk Üniversitesi Sosyal Bilimler Enstitüsü Dergisi, (20), 577-595.

Taş Öz, P. (2012). Sinemasal anlatıda anlatıcının konumu ve önemi. Marmara İletişim Dergisi, (19), 78-93.

Turner, G. (2016). Ingiliz Kültürel Çalışmaları. Çev. Deniz Özçetin ve Burak Özçetin. Ankara: Heretik Yayınları.

Van D., Teun A. (2015). Söylem ve ideoloji: çokalanlı bir yaklaşım. Söylem ve ideoloji (ss. 15- 100). Haz. Barış Çoban ve Zeynep Özarslan. İstanbul: Su Yayınevi. 
Warren, K., (2010). Persepolis: Animation, Representation and the Power of the Personal Story, Screen Education 58, 117-23.

Wayne, M. (2006). Marksizm ve medya araştırmaları anahtar kavramlar. Çağdaş Eğilimler. Çev. Barış Cezar. (2. Baskı). İstanbul: Yordam Kitap Basın ve Yayın.

Wayne, M. (2011). Politik film: üçüncü sinema'nm diyalektiği. Çev. Ertan Yılmaz. İstanbul: Yordam Kitap.

Yaktıl, G. (1995). Anlatı kuramı açısından "Hayallerim, Aşkım ve Sen. Kurgu Anadolu Üniversitesi İletişim Bilimleri Fakültesi Uluslararası Hakemli İletişim Dergisi, 13(13), 125-138.

Yıldırım, A. \& Şimşek, H. (2008). Sosyal Bilimlerde Nitel Araştırma Yöntemleri, (6. Baskı), Ankara: Seçkin Yayıncılık.

Zengin, E. (2018) Althusser'in Düşüncesinde İdeoloji, Özne Ve Bilinç İlişkisi. Anasay Dergisi, 2(5), 51-70. 